This is an author produced version of a paper published in Reproduction in Domestic Animals.

This paper has been peer-reviewed but may not include the final publisher proof-corrections or pagination.

Citation for the published paper:

Holst, B.S. (2017) Diagnostic possibilities from a serum sample - Clinical value of new methods within small animal reproduction, with focus on antiMüllerian hormone. Reproduction in Domestic Animals. Volume: 52, Number: S2, pp 303-309.

http://dx.doi.org/10.1111/rda.12856.

Access to the published version may require journal subscription.

Published with permission from: Wiley.

Standard set statement from the publisher:

"This is the peer reviewed version of the following article: Holst, B. (2017),

Diagnostic possibilities from a serum sample-Clinical value of new methods within small animal reproduction, with focus on anti-Müllerian hormone. Reprod Dom Anim, 52: 303-309, which has been published in final form at http://dx.doi.org/10.1111/rda.12856. This article may be used for non-commercial purposes in accordance with Wiley Terms and Conditions for Self-Archiving."

Epsilon Open Archive http://epsilon.slu.se 
Uppsala, Sweden

Diagnostic possibilities from a serum sample - clinical value of new methods within small animal reproduction, with focus on anti-Müllerian hormone

BS Holst

Swedish University of Agricultural Sciences, Department of Clinical Sciences, PO Box 7054, SE-750 07 Uppsala, Sweden

e-mail: Bodil.Strom-Holst@slu.se

Abridged title: AMH analysis in small animal reproduction 


\section{Diagnostic possibilities from a serum sample - clinical value of new methods within small animal reproduction, with focus on anti-Müllerian hormone}

\section{Contents}

During the last decade, analysis of anti-Müllerian hormone (AMH), highly conserved between mammalian species, has contributed to new information in reproductive endocrinology, due to clinically available diagnostic assays. AMH is produced solely in the gonads; in the Sertoli cells of testes and granulosa cells of the ovary, and thus offers possibilities to diagnose physiologic and pathologic conditions involving these organs. This paper reviews indications for AMH analysis in cats and dogs, include diagnosing presence of gonads, and granulosa or Sertoli cell tumors. Diagnostic challenges are addressed. One specific organ, the prostate, is commonly affected by pathologic changes in older dogs. A commercial assay for analyzing canine prostatic specific esterase (CPSE) enables analysis of CPSE in clinical practice, of potential value of in the work-up of benign prostatic hyperplasia in male dogs. This is described in this review, as is a new method for analysis of steroids: liquid chromatography-tandem mass spectrometry LCMS/MS. Steroids have since long been analyzed in studies on reproduction, and LCMS/MS has the advantage of allowing analysis of panels of multiple steroids from small sample volumes. Altogether, these available methods may give new insights into small animal reproduction, and are valuable tools for the practicing veterinarian.

Keywords: AMH, castration, BPH, LC-MS/MS

\section{Introduction}

The development of small animal reproduction is dependent on suitable tools for studies of physiological and pathological phenomena. Recently, commercial immunoassays have become available for analysis of anti-Müllerian hormone (AMH) and canine prostate specific esterase (CPSE). These methods allows studies of gonadal function and of the prostate, respectively, and may thus contribute to new insights that can be valuable for the clinician working within the field of reproduction (Holst and Dreimanis 2015; Levy et al. 
2014; Place et al. 2011; Themmen et al. 2016; Turna Yilmaz et al. 2015). Traditionally, steroid analysis using immunoassays have dominated reproductive endocrinology. With a new method; liquid chromatography and tandem mass spectrometry (LC-MS/MS), analysis of panels of steroid hormones is possible. This enables a more complete picture of ongoing events within small animal reproduction (Holst et al. 2015).

\section{Anti-Müllerian hormone (AMH)}

Anti-Müllerian hormone (AMH), also called Müllerian inhibiting substance (MIS), is a glycoprotein that belongs to the transforming growth factor (TGF) $\beta$ family (Josso and di Clemente 1999). The use of AMH analyses in human reproductive endocrinology has increased over the last decade, mainly for assessing the ovarian reserve (Brodin et al. 2013; Nelson and La Marca 2011).

AMH is found exclusively in gonadal somatic cells; Sertoli cells in males and granulosa cells in females (Josso and di Clemente 1999). An important biological role, and the reason for the name of the hormone, is the triggering of the regression of fetal Müllerian ducts in males (Josso et al. 2013). The immature Sertoli cell produces high concentrations of $\mathrm{AMH}$, and strong expression has been described in Sertoli cells of fetal canine testicles (Banco et al. 2012). After puberty, testosterone inhibits AMH production through the androgen receptor, that is expressed by mature Sertoli cells (Josso et al. 2013), Figure 1. AMH also inhibits the activity of Leydig cells (Racine et al. 1998). 
Figure 1. (Please see caption at the end of this document.)

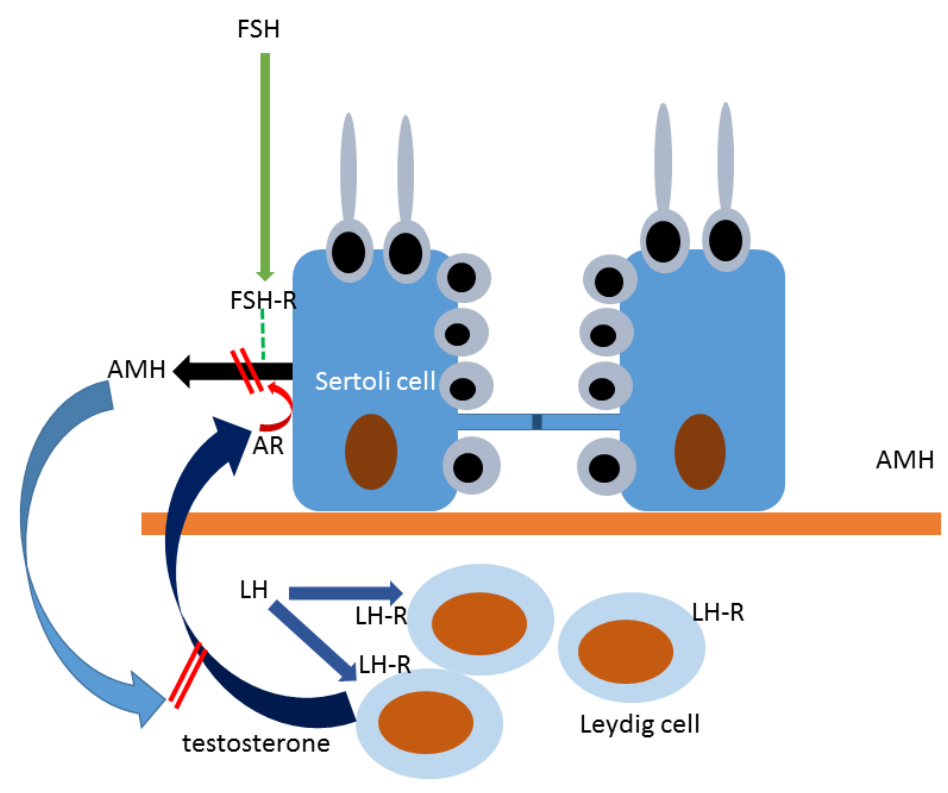

In females, AMH is expressed mainly in pre-antral and small antral follicles, in dogs as in other species (Nagashima et al. 2016). AMH has been shown to inhibit initiation of primordial follicle growth (Durlinger et al. 2002), thus protecting the ovary from a premature exhaustion of the follicle pool. In addition, AMH has been shown to inhibit the stimulatory effect of FSH on growth of preantral and small antral follicles (Durlinger et al. 2001), an effect that is important during cyclic recruitment. 
Figure 2. (Please see caption at the end of this document.)

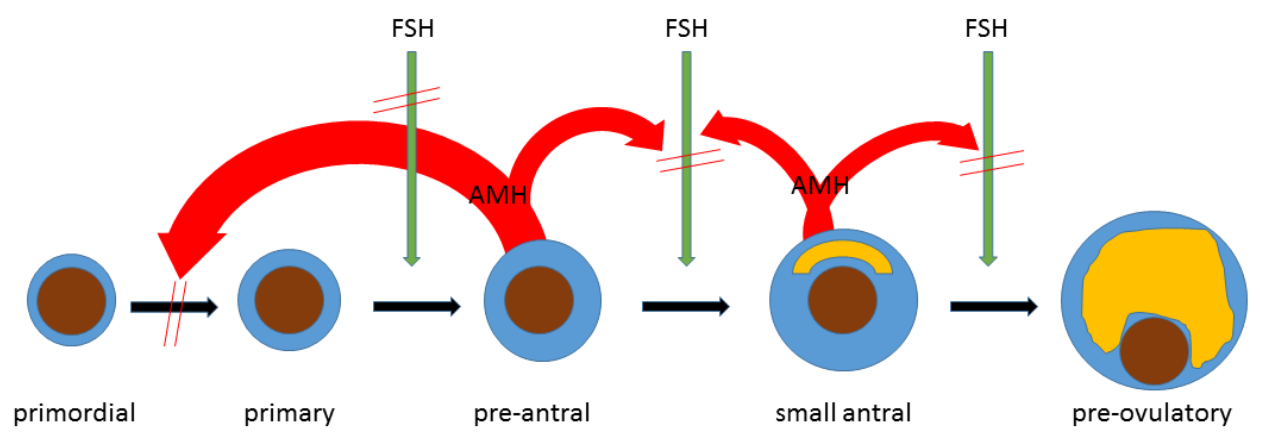

Clinical implications of AMH in male dogs and cats (summarized in Table 1, end of this document.) 


\section{Cryptorchidism or castration}

$\mathrm{AMH}$ is a reliable test for diagnosing castration status in male cats (Axner and Strom Holst 2015). AMH concentrations are high in adult males, and even higher before puberty (Axner and Strom Holst 2015; Josso et al. 2013). Analysis of AMH can thus be used for detection of testicles irrespective of age of the male. In dogs, calves and hoses, analysis of AMH was predictive of testicular tissue, irrespective if it was abdominal or not (Claes et al. 2013; Gharagozlou et al. 2014; Kitahara et al. 2012a). Analysis of AMH is not suitable for evaluation of chemical castration (e.g. with deslorelin), as this has been seen to result in increased concentrations of AMH in dogs (above the highest standard point, unpublished personal observation).

\section{Presence of Sertoli cell tumors}

AMH has been described to be a useful marker for immature and neoplastic canine Sertoli cells (Banco et al. 2012). Dogs with testicular tumors of Sertoli cell origin had a ten to thousand times higher serum concentration than healthy dogs or dogs with other testicular pathologies (Ano et al. 2014; Holst and Dreimanis 2015). In the diagnostic workup of testicular tumors, other tests may also be helpful, such as preputial cytology when estrogen production is suspected (Dreimanis et al. 2012).

\section{Infertility investigations}

Important functions are attributed to the Sertoli cell, including a sustentacular and nutritive role for germ cells, organization of spermiation, production of endocrine and paracrine substances that regulate spermatogenesis, secretion of androgen binding protein, and interaction with the Leydig cells (Holstein et al 2003). Because the serum AMH concentration reflects Sertoli cell function, it may constitute an additional diagnostic parameter in male subfertility (Iliadou et al. 2015). In men, the concentration of AMH in seminal plasma, but not in serum, was shown to be associated with sperm count and motility (Andersen et al. 2016). At present, there are no published studies on the relationship between $\mathrm{AMH}$ and fertility in male cats or dogs. 


\section{Clinical implications of AMH in female dogs and cats}

\section{Presence of ovaries or ovarian remnants}

The analysis of AMH can distinguish ovariohysterectomized from intact cats and dogs (Place et al. 2011). In a recent study, 27/30 (90\%) of intact and all 29 spayed bitches bitches were correctly identified (Themmen et al. 2016). This can be compared to measurement of luteinizing hormone (LH) in serum, that correctly identified $78 \%$ of intact and $98 \%$ of ovariectomized bitchese $(n=300)$ (Lofstedt and Vanleeuwen 2002). In cats, analysis of AMH has been described as a reliable test for differentiating spayed from intact females, correctly identifying all 16 intact and 15 spayed females (Axner and Strom Holst 2015). Using LH, all 16 intact and 14/15 ( $\mathrm{n}=94 \%)$ of the spayed cats were correctly diagnosed (Rohlertz et al. 2012).

AMH has been used for diagnosing ovarian remnants in cats (Place et al. 2011) and dogs (Turna Yilmaz et al. 2015). Significantly lower mean serum concentrations of AMH were detected in spayed bitches $(0.28 \pm 0.09 \mathrm{ng} / \mathrm{ml})$ than in intact bitches $(4.26 \pm 0.82 \mathrm{ng} / \mathrm{ml})$ or bitches with ovarian remnants $(4.4 \pm 1.09 \mathrm{ng} / \mathrm{ml})$, using the AMH enzyme linked immunosorbent assay (ELISA) from Ansh Labs (Webster, USA) (Turna Yilmaz et al. 2015).

An effect of age has not been reported for dogs or cats, but in humans, concentrations of AMH decrease with age independent of number of pregnancies (La Marca et al. 2012), and concentrations below the detection limit have been shown both in ovariectomized and postmenopausal women (La Marca et al. 2005).

\section{Presence of granulosa cell tumors}

AMH is a specific marker for granulosa cell tumors (GCT) in women (La Marca and Volpe 2007), mares (Ball et al. 2013) and cows (El-Sheikh Ali et al. 2013; Kitahara et al. 2012b), with high concentrations in females with GCTs. There are no published reports of this use in cats or dogs, but in our lab we have analyzed high concentrations of AMH (above the highest standard point) in two bitches with confirmed GCTs. 


\section{Infertility investigations}

In humans, elevated AMH concentrations are useful for diagnosing the polycystic ovarian syndrome, a common cause of anovulatory infertility (Jamil et al. 2016). Obese patients with reduced fertility due to reduced ovarian reserve and dysfunctional folliculogenesis have low concentrations of AMH (Jamil et al. 2016). AMH concentrations vary between intact individuals, but concentrations of AMH are considered relatively independent of cycle stage in cows (Monniaux et al. 2012) and women (van Disseldorp et al. 2010).

There is a large inter-individual variation in both dogs and cats (Axner and Strom Holst 2015; Nagashima et al. 2016; Place et al. 2011), with an unknown relationship to fertility. The use of AMH analysis in infertility investigations has not been evaluated for these species.

\section{In vitro fertilization techniques and determination of the ovarian reserve}

The concentration of AMH reflects the antral follicle count (AFC) in cattle (Ireland et al. 2011) and women. Analysis of AMH concentrations has been useful for predicting follicular and ovulatory response to gonadotrophin treatment for embryo transfer in cows (Rico et al. 2012), and is also predictive for embryo production in the goat (Monniaux et al. 2011). It is a widely used tool in human IVF settings (Brodin et al. 2013). In bitches, an AMH peak has been described preceding the LH peak, coinciding with the rise and fall in the number of early antral follicles (Nagashima et al. 2016). The rise in AMH has therefore been suggested to enable prediction of onset of estrus, and monitoring AMH may enable prediction of ovulation ten days in advance. This may improve collection of pre-ovulatory oocytes for IVF. The correlation between AMH and the AFC is of potential value in endangered canine populations, e.g. for planning of best breeding pairs and population planning with aging individuals (Nagashima et al. 2016).

\section{AMH in disorders of sexual differentiation (DSD)}

Analysis of AMH can be used clinically when investigating disorders of sex development in humans (Josso et al. 2013; Lindhardt Johansen et al. 2013). For example, men with the Klinefelter syndrome (47, XXY) have subnormal AMH concentrations after puberty that 
may be explained by a progressive destruction of testicular tissue (Aksglaede et al. 2011). In virilized females, AMH concentrations within the male reference range is seen in cases with testicular tissue, whereas AMH concentrations within the female reference range can be seen in cases with a high production of adrenal androgens (Josso et al. 2013; Lindhardt Johansen et al. 2013). Several DSDs have been reported in dogs and cats (Meyers-Wallen 2012), but there are as yet no reports on the use of AMH analysis in DSD investigations in these species.

\section{Interpretation of AMH test results with different immunoassays}

Initially, two commercial ELISAs available for human samples, one from Diagnostic Systems Lab (DSL) and one from Immunotech (IOT) (Nelson and La Marca 2011), were widely used also for other species. They were followed by a third assay, AMH Gen II (Beckman coulter). AMH Gen II assay was calibrated against the IOT, and values achieved are in the same range (Kumar et al. 2010). Compared with the DSL assay, one report found values to be approximately $40 \%$ higher with the AMH Gen II assay (Wallace et al. 2011), while another study instead reported values that were approximately $20 \%$ lower (Rustamov et al. 2012). Account must be taken to these differences when interpreting results using the different assays. One factor that may influence the results is the storage time, which has been reported to result in increasing values when whole blood ( $\sim 30 \%$ after 3.5 days) or serum ( $\sim 30 \%$ after 2 days) was stored at room temperature (Fleming et al. 2013; Rustamov et al. 2012). This increase during storage may be due to a dissociation of the AMH molecule (Rustamov et al. 2012). Another potential cause is interference by complement (Weber et al. 1990). Since 2013, a pre-mixing step is introduced for the AMH Gen II assay, increasing reproducibility of measurements (Han et al. 2014). Recently, the same antibodies as used in the AMH Gen II assay have been used in two fully automated immunoassays, with higher analytical sensitivity (van Helden and Weiskirchen 2015). Studies on dogs or cats have not been published using the automated methods. Commercial ELISAs developed for use in dogs have recently become available and used (Turna Yilmaz et al. 2015). In Table 1, the different ELISAs that have been used for cats and dogs are shown.

In the study by Place and co-workers, using the DSL assay, one spayed bitch was considered having a falsely high AMH concentration, being a statistical outlier (Place et al. 
2011). In our laboratory, we have had single cases of high concentrations of AMH in neutered males/spayed female dogs. This may be due to remnant gonadal tissue. It may also be caused by assay interference; presence of heterophilic antibodies has been reported to cause falsely high concentrations of AMH in humans (Cappy et al. 2013). Except for this single bitch, all spayed bitches had AMH concentrations below the lowest standard point (Place et al. 2011). However, several intact bitches, especially bitches < 6 months of age, had non-detectable AMH concentrations, leading to overlapping results (Place et al. 2011). This overlap is a potential problem when assessing presence of gonads in dogs. The degree of overlap may vary depending on which assay is used. In the study by Turna Yilmaz et al (Turna Yilmaz et al. 2015), all prepubertal bitches had measurable concentrations.

In cats, one study reported all spayed females and neutered males to have non-detectable concentrations, whereas all intact cats had measurable concentrations, and there was thus no overlap (Axner and Strom Holst 2015). Higher concentrations in cats than in dogs have been reported previously (Place et al. 2011), reducing the difficulty of interpretation of the results due to overlap, and the problem with overlap seems to be less.

The concentration reported for intact bitches in the study by Turna Yilmaz et al $(4.26 \pm 0.82 \mathrm{ng} / \mathrm{ml})$ (Turna Yilmaz et al. 2015) and Themmen et al $(3.9 \pm 2.7 \mathrm{ng} / \mathrm{ml})$ (Themmen et al. 2016), both using the Ansh ELISA, are high compared to other studies: range $0.1-0.41 \mathrm{ng} / \mathrm{ml}$ (Place et al. 2011), using the DSL ELISA, and $0.3 \pm 0.01 \mathrm{ng} / \mathrm{ml}$ to $0.64 \pm 0.03 \mathrm{ng} / \mathrm{ml}$ during proestrus (Nagashima et al. 2016), using the AMH Gen II ELISA. It is important that each laboratory establishes own reference intervals for their test. The importance of developing an international standard for $\mathrm{AMH}$ has been stressed in human medicine ( $\mathrm{Li}$ et al. 2012), and is certainly needed also in veterinary medicine. Values reported as $\mathrm{ng} / \mathrm{ml}(\mathrm{pg} / \mathrm{l})$ can be converted to SI units: $1 \mathrm{ng} / \mathrm{ml}=7.14 \mathrm{pM}$.

\section{Table 1.}

\section{Another new diagnostic possibility: Canine prostate specific esterase (CPSE)}

A commercial ELISA has become available for the analysis of canine prostate specific esterase (CPSE). CPSE is an arginine esterase and the major secretory product of the canine prostate (Chapdelaine et al. 1984). CPSE is regulated by testosterone (Juniewicz et 
al. 1990). Serum CPSE activity has been described to be significantly higher in dogs with BPH than in normal dogs (Bell et al. 1995; Wolf et al. 2012), but did not differ between dogs with BPH, bacterial prostatitis and prostatic carcinoma (Bell et al. 1995). CPSE is thus a potentially valuable biomarker for prostatic enlargement, and can be included in the diagnostic workup of dogs with clinical signs of BPH and for screening of geriatric dogs (Levy et al. 2014).

\section{New possibilities with liquid chromatography tandem mass spectrometry (LC- MS/MS)}

An increasing number of human clinical pathology laboratories are offering liquid chromatography tandem mass spectrometry, LC-MS/MS, for analyses of steroid hormones (Field 2013; Stanczyk and Clarke 2010). The method is often replacing immunoassays for these hormones because of better specificity and sensitivity and the high reproducibility (Shackleton 2010). LC-MS/MS has been used for the simultaneous quantitation of multiple steroids in several species (Koren et al. 2012). One great advantage is the possibility to quantify panels of steroid hormones and patterns of steroid hormone metabolites (Stanczyk and Clarke 2010). In addition, LC-MS/MS allows quantitation of hormones for which no immunoassays are commercially available, e.g. pregnanes (Holst et al. 2015). The amount of serum needed is small, and the technique is valuable when the sample volume is limited, such as in small breeds or young animals. The method has been used to study steroid profiles in dogs with X-linked muscular dystrophy (Martins-Junior et al. 2015) and to study steroid profiles in pregnant dogs (Holst et al. 2015). The method is not common in veterinary clinical pathology laboratories and the availability for routine diagnostics within veterinary medicine is thus limited, but it is a promising method for the future.

\section{Conclusion}

Analysis of AMH, a hormone specific for the mammalian gonads, enables new possibilities for diagnosing presence of gonads and gonadal tumors. The value of AMH in infertility investigations and IVF settings remains to be investigated. A new methodology, 
LC-MS/MS, enables analysis of panels of steroids. Analysis of CPSE can be helpful in diagnostic workups of geriatric dogs.

\section{References}

Aksglaede L, Christiansen P, Sorensen K, Boas M, Linneberg A, Main KM, Andersson AM, Skakkebaek NE, Juul A, 2011: Serum concentrations of Anti-Mullerian Hormone (AMH) in 95 patients with Klinefelter syndrome with or without cryptorchidism. Acta Paediatr 100, 839-845. Andersen JM, Herning H, Witczak O, Haugen TB, 2016: Anti-Mullerian hormone in seminal plasma and serum: association with sperm count and sperm motility. Hum Reprod

Ano H, Hidaka Y, Katamoto H, 2014: Evaluation of anti-Mullerian hormone in a dog with a Sertoli cell tumour. Vet Dermatol 25, 142-145, e141.

Axner E, Strom Holst B, 2015: Concentrations of anti-Mullerian hormone in the domestic cat. Relation with spay or neuter status and serum estradiol. Theriogenology 83, 817-821.

Ball BA, Almeida J, Conley AJ, 2013: Determination of serum anti-Mullerian hormone concentrations for the diagnosis of granulosa-cell tumours in mares. Equine Vet J 45, 199-203. Banco B, Veronesi MC, Giudice C, Rota A, Grieco V, 2012: Immunohistochemical evaluation of the expression of anti-Mullerian hormone in mature, immature and neoplastic canine Sertoli cells. $\mathrm{J}$ Comp Pathol 146, 18-23.

Bell FW, Klausner JS, Hayden DW, Lund EM, Liebenstein BB, Feeney DA, Johnston SD, Shivers JL, Ewing CM, Isaacs WB, 1995: Evaluation of serum and seminal plasma markers in the diagnosis of canine prostatic disorders. J Vet Intern Med 9, 149-153.

Brodin T, Hadziosmanovic N, Berglund L, Olovsson M, Holte J, 2013: Antimullerian hormone levels are strongly associated with live-birth rates after assisted reproduction. J Clin Endocrinol Metab 98, 1107-1114.

Cappy H, Pigny P, Leroy-Billiard M, Dewailly D, Catteau-Jonard S, 2013: Falsely elevated serum antimullerian hormone level in a context of heterophilic interference. Fertil Steril 99, 1729-1732. Chapdelaine P, Dube JY, Frenette G, Tremblay RR, 1984: Identification of arginine esterase as the major androgen-dependent protein secreted by dog prostate and preliminary molecular characterization in seminal plasma. J Androl 5, 206-210.

Claes A, Ball BA, Almeida J, Corbin CJ, Conley AJ, 2013: Serum anti-Mullerian hormone concentrations in stallions: developmental changes, seasonal variation, and differences between intact stallions, cryptorchid stallions, and geldings. Theriogenology 79, 1229-1235.

Dreimanis U, Vargmar K, Falk T, Cigut M, Toresson L, 2012: Evaluation of preputial cytology in diagnosing oestrogen producing testicular tumours in dogs. J Small Anim Pract 53, 536-541.

Durlinger AL, Gruijters MJ, Kramer P, Karels B, Ingraham HA, Nachtigal MW, Uilenbroek JT, Grootegoed JA, Themmen AP, 2002: Anti-Mullerian hormone inhibits initiation of primordial follicle growth in the mouse ovary. Endocrinology 143, 1076-1084.

Durlinger AL, Gruijters MJ, Kramer P, Karels B, Kumar TR, Matzuk MM, Rose UM, De Jong FH, Uilenbroek JT, Grootegoed JA, Themmen AP, 2001: Anti-Mullerian hormone attenuates the effects of FSH on follicle development in the mouse ovary. Endocrinology 142, 4891-4899. El-Sheikh Ali H, Kitahara G, Nibe K, Yamaguchi R, Horii Y, Zaabel S, Osawa T, 2013: Plasma anti-Mullerian hormone as a biomarker for bovine granulosa-theca cell tumors: comparison with immunoreactive inhibin and ovarian steroid concentrations. Theriogenology 80, 940-949.

Field HP, 2013: Tandem mass spectrometry in hormone measurement. Methods Mol Biol 1065, 45-74.

Fleming R, Fairbairn C, Blaney C, Lucas D, Gaudoin M, 2013: Stability of AMH measurement in blood and avoidance of proteolytic changes. Reprod Biomed Online 26, 130-132.

Gharagozlou F, Youssefi R, Akbarinejad V, Mohammadkhani NI, Shahpoorzadeh T, 2014: AntiMullerian hormone: a potential biomarker for differential diagnosis of cryptorchidism in dogs. Vet Rec 175, 460. 
Han X, Mcshane M, Sahertian R, White C, Ledger W, 2014: Pre-mixing serum samples with assay buffer is a prerequisite for reproducible anti-Mullerian hormone measurement using the Beckman Coulter Gen II assay. Hum Reprod 29, 1042-1048.

Holst BS, Dreimanis U, 2015: Anti-Mullerian hormone: a potentially useful biomarker for the diagnosis of canine Sertoli cell tumours. BMC Vet Res 11, 166.

Holst BS, Kushnir MM, Bergquist J, 2015: Liquid chromatography-tandem mass spectrometry (LC-MS/MS) for analysis of endogenous steroids in the luteal phase and early pregnancy in dogs: a pilot study. Vet Clin Pathol

Iliadou PK, Tsametis C, Kaprara A, Papadimas I, Goulis DG, 2015: The Sertoli cell: Novel clinical potentiality. Hormones (Athens) 14, 504-514.

Ireland JJ, Smith GW, Scheetz D, Jimenez-Krassel F, Folger JK, Ireland JL, Mossa F, Lonergan P, Evans AC, 2011: Does size matter in females? An overview of the impact of the high variation in the ovarian reserve on ovarian function and fertility, utility of anti-Mullerian hormone as a diagnostic marker for fertility and causes of variation in the ovarian reserve in cattle. Reprod Fertil Dev 23, 1-14.

Jamil Z, Fatima SS, Ahmed K, Malik R, 2016: Anti-Mullerian Hormone: Above and Beyond Conventional Ovarian Reserve Markers. Dis Markers 2016, 5246217.

Josso N, Di Clemente N, 1999: TGF-beta Family Members and Gonadal Development. Trends Endocrinol Metab 10, 216-222.

Josso N, Di Clemente N, Gouedard L, 2001: Anti-Mullerian hormone and its receptors. Mol Cell Endocrinol 179, 25-32.

Josso N, Rey RA, Picard JY, 2013: Anti-mullerian hormone: a valuable addition to the toolbox of the pediatric endocrinologist. Int J Endocrinol 2013, 674105.

Juniewicz PE, Barbolt TA, Egy MA, Frenette G, Dube JY, Tremblay RR, 1990: Effects of androgen and antiandrogen treatment on canine prostatic arginine esterase. Prostate 17, 101-111.

Kitahara G, El-Sheikh Ali H, Sato T, Kobayashi I, Hemmi K, Shirao Y, Kamimura S, 2012a: AntiMullerian hormone (AMH) profiles as a novel biomarker to evaluate the existence of a functional cryptorchid testis in Japanese Black calves. J Reprod Dev 58, 310-315.

Kitahara G, Nambo Y, El-Sheikh Ali H, Kajisa M, Tani M, Nibe K, Kamimura S, 2012b: AntiMullerian hormone profiles as a novel biomarker to diagnose granulosa-theca cell tumors in cattle. J Reprod Dev 58, 98-104.

Koren L, Ng ES, Soma KK, Wynne-Edwards KE, 2012: Sample preparation and liquid chromatography-tandem mass spectrometry for multiple steroids in mammalian and avian circulation. PLoS One 7, e32496.

Kumar A, Kalra B, Patel A, Mcdavid L, Roudebush WE, 2010: Development of a second generation anti-Mullerian hormone (AMH) ELISA. J Immunol Methods 362, 51-59.

La Marca A, De Leo V, Giulini S, Orvieto R, Malmusi S, Giannella L, Volpe A, 2005: AntiMullerian hormone in premenopausal women and after spontaneous or surgically induced menopause. J Soc Gynecol Investig 12, 545-548.

La Marca A, Spada E, Grisendi V, Argento C, Papaleo E, Milani S, Volpe A, 2012: Normal serum anti-Mullerian hormone levels in the general female population and the relationship with reproductive history. Eur J Obstet Gynecol Reprod Biol 163, 180-184.

La Marca A, Volpe A, 2007: The Anti-Mullerian hormone and ovarian cancer. Hum Reprod Update 13, 265-273.

Levy X, Nizanski W, Von Heimendahl A, Mimouni P, 2014: Diagnosis of common prostatic conditions in dogs: an update. Reprod Domest Anim 49 Suppl 2, 50-57.

Li HW, Ng EH, Wong BP, Anderson RA, Ho PC, Yeung WS, 2012: Correlation between three assay systems for anti-Mullerian hormone (AMH) determination. J Assist Reprod Genet 29, 14431446.

Lindhardt Johansen M, Hagen CP, Johannsen TH, Main KM, Picard JY, Jorgensen A, Rajpert-De Meyts E, Juul A, 2013: Anti-mullerian hormone and its clinical use in pediatrics with special emphasis on disorders of sex development. Int J Endocrinol 2013, 198698.

Lofstedt RM, Vanleeuwen JA, 2002: Evaluation of a commercially available luteinizing hormone test for its ability to distinguish between ovariectomized and sexually intact bitches. J Am Vet Med Assoc 220, 1331-1335. 
Martins-Junior HA, Simas RC, Brolio MP, Ferreira CR, Perecin F, Nogueira Gde P, Miglino MA, Martins DS, Eberlin MN, Ambrosio CE, 2015: Profiles of Steroid Hormones in Canine X-Linked Muscular Dystrophy via Stable Isotope Dilution LC-MS/MS. PLoS One 10, e0126585.

Meyers-Wallen VN, 2012: Gonadal and sex differentiation abnormalities of dogs and cats. Sex Dev 6, 46-60.

Monniaux D, Baril G, Laine AL, Jarrier P, Poulin N, Cognie J, Fabre S, 2011: Anti-Mullerian hormone as a predictive endocrine marker for embryo production in the goat. Reproduction 142, 845-854.

Monniaux D, Drouilhet L, Rico C, Estienne A, Jarrier P, Touze JL, Sapa J, Phocas F, Dupont J, Dalbies-Tran R, Fabre S, 2012: Regulation of anti-Mullerian hormone production in domestic animals. Reprod Fertil Dev 25, 1-16.

Nagashima JB, Hansen BS, Songsasen N, Travis AJ, Place NJ, 2016: Anti-Mullerian Hormone in the Domestic Dog during the Anestrus to Oestrous Transition. Reprod Domest Anim 51, 158-164. Nelson SM, La Marca A, 2011: The journey from the old to the new AMH assay: how to avoid getting lost in the values. Reprod Biomed Online 23, 411-420.

Place NJ, Hansen BS, Cheraskin JL, Cudney SE, Flanders JA, Newmark AD, Barry B, Scarlett JM, 2011: Measurement of serum anti-Mullerian hormone concentration in female dogs and cats before and after ovariohysterectomy. J Vet Diagn Invest 23, 524-527.

Racine C, Rey R, Forest MG, Louis F, Ferre A, Huhtaniemi I, Josso N, Di Clemente N, 1998:

Receptors for anti-mullerian hormone on Leydig cells are responsible for its effects on steroidogenesis and cell differentiation. Proc Natl Acad Sci U S A 95, 594-599.

Rico C, Drouilhet L, Salvetti P, Dalbies-Tran R, Jarrier P, Touze JL, Pillet E, Ponsart C, Fabre S, Monniaux D, 2012: Determination of anti-Mullerian hormone concentrations in blood as a tool to select Holstein donor cows for embryo production: from the laboratory to the farm. Reprod Fertil Dev 24, 932-944.

Rohlertz M, Strom Holst B, Axner E, 2012: Comparison of the GnRH-stimulation test and a semiquantitative quick test for LH to diagnose presence of ovaries in the female domestic cat. Theriogenology 78, 1901-1906.

Rustamov O, Smith A, Roberts SA, Yates AP, Fitzgerald C, Krishnan M, Nardo LG, Pemberton PW, 2012: Anti-Mullerian hormone: poor assay reproducibility in a large cohort of subjects suggests sample instability. Hum Reprod 27, 3085-3091.

Shackleton C, 2010: Clinical steroid mass spectrometry: a 45-year history culminating in HPLCMS/MS becoming an essential tool for patient diagnosis. J Steroid Biochem Mol Biol 121, 481490.

Stanczyk FZ, Clarke NJ, 2010: Advantages and challenges of mass spectrometry assays for steroid hormones. J Steroid Biochem Mol Biol 121, 491-495.

Themmen AP, Kalra B, Visser JA, Kumar A, Savjani G, De Gier J, Jaques S, 2016: The use of anti-Mullerian hormone as diagnostic for gonadectomy status in dogs. Theriogenology 86, 14671474.

Turna Yilmaz O, Toydemir TS, Kirsan I, Gunay Ucmak Z, Caliskan Karacam E, 2015: AntiMullerian hormone as a diagnostic tool for ovarian remnant syndrome in bitches. Vet Res Commun 39, 159-162.

Wallace AM, Faye SA, Fleming R, Nelson SM, 2011: A multicentre evaluation of the new Beckman Coulter anti-Mullerian hormone immunoassay (AMH Gen II). Ann Clin Biochem 48, 370-373.

Van Disseldorp J, Lambalk CB, Kwee J, Looman CW, Eijkemans MJ, Fauser BC, Broekmans FJ, 2010: Comparison of inter- and intra-cycle variability of anti-Mullerian hormone and antral follicle counts. Hum Reprod 25, 221-227.

Van Helden J, Weiskirchen R, 2015: Performance of the two new fully automated anti-Mullerian hormone immunoassays compared with the clinical standard assay. Hum Reprod 30, 1918-1926. Weber TH, Kapyaho KI, Tanner P, 1990: Endogenous interference in immunoassays in clinical chemistry. A review. Scand J Clin Lab Invest Suppl 201, 77-82.

Visser JA, Themmen AP, 2005: Anti-Mullerian hormone and folliculogenesis. Mol Cell Endocrinol 234, 81-86. 
Wolf K, Kayacelebi H, Urhausen C, Piechotta M, Mischke R, Kramer S, Einspanier A, Oei CH, Gunzel-Apel A, 2012: Testicular steroids, prolactin, relaxin and prostate gland markers in peripheral blood and seminal plasma of normal dogs and dogs with prostatic hyperplasia. Reprod Domest Anim 47 Suppl 6, 243-246. 
Table 1. Use of AMH in clinical studies in dogs and cats

\begin{tabular}{|c|c|c|c|c|}
\hline Species & Indication & Test kit & No of animals & Reference \\
\hline Dog & $\begin{array}{l}\text { Presence of ovaries in } \\
\text { females }\end{array}$ & $\begin{array}{l}\text { DSL/Ansh } \\
\text { Labs }\end{array}$ & $\begin{array}{l}112 \text { ( } 2 \text { ovarian } \\
\text { remnants)/94 }\end{array}$ & $\begin{array}{l}\text { (Place et al. } \\
\text { 2011)/(Themmen } \\
\text { et al. 2016) }\end{array}$ \\
\hline Dog & $\begin{array}{l}\text { Presence of ovarian } \\
\text { remnants }\end{array}$ & Ansh Labs & 46 & $\begin{array}{l}\text { (Turna Yilmaz et } \\
\text { al. 2015) }\end{array}$ \\
\hline Dog & $\begin{array}{l}\text { Presence of testes in } \\
\text { males }\end{array}$ & $\begin{array}{l}\text { AMH Gen } \\
\text { II/ AMH } \\
\text { Gen II/Ansh } \\
\text { Labs }\end{array}$ & $24 / 5 / 98$ & $\begin{array}{l}\text { (Gharagozlou et } \\
\text { al. 2014)/(Ano et } \\
\text { al. } \\
\text { 2014)/(Themmen } \\
\text { et al. 2016) }\end{array}$ \\
\hline Dog & $\begin{array}{l}\text { Presence of Sertoli cell } \\
\text { tumors }\end{array}$ & AMH Gen II & $47 / 5$ & $\begin{array}{l}\text { (Holst and } \\
\text { Dreimanis } \\
\text { 2015)/(Ano et al. } \\
\text { 2014) }\end{array}$ \\
\hline Dog & $\begin{array}{l}\text { Study the transition } \\
\text { from anestrus to estrus }\end{array}$ & AMH Gen II & 5 & $\begin{array}{l}\text { (Nagashima et } \\
\text { al. 2016) }\end{array}$ \\
\hline Cat & $\begin{array}{l}\text { Presence of gonads in } \\
\text { females and males }\end{array}$ & AMH Gen II & $31+27 / 32$ & $\begin{array}{l}\text { (Axner and } \\
\text { Strom Holst } \\
\text { 2015)/(Place et } \\
\text { al. 2011) }\end{array}$ \\
\hline
\end{tabular}




\section{Captions:}

\section{Figure 1.}

Testosterone inhibits AMH production through the androgen receptor, that is expressed by mature Sertoli cells (Josso et al. 2013). AMH reduces the testosterone production via an AMH receptor on the Leydig cells (Racine et al. 1998). FSH has a stimulatory effect on AMH expression that is evident the absence of androgens, like in the immature testis (Josso et al. 2001). The information on the function of AMH in males is from experiments carried out in laboratory animals, mostly mice and rats. FSH: follicle stimulating hormone, FSH-R: FSH- receptor, AMH: anti-Müllerian hormone, AR: androgen receptor, LH: luteinizing hormone, LH-R: LH- receptor.

\section{Figure 2.}

AMH is produced mainly in pre-antral and small antral follicles, that has been shown in several species, including dogs (Nagashima et al. 2016). In mice, it has been shown that AMH inhibits initiation of primordial cell growth, probably due to a direct effect of AMH on the primordial follicle, and FSH-stimulated follicle growth, by decreasing the sensitivity of growing follicles to AMH (Durlinger et al. 2002; Durlinger et al. 2001). $\mathrm{AMH}$ may thus play a role in the determination of follicles to undergo selection or atresia (Visser and Themmen 2005). Green arrows: stimulatory function of FSH. Red arrows: inhibitory effect of AMH. Brown: Oocyte. Blue: Granulosa cells. Yellow: antrum.

\section{Table 1.}

Use of AMH in clinical studies in dogs and cats 